University of Nebraska - Lincoln

DigitalCommons@University of Nebraska - Lincoln

Publications, Agencies and Staff of the U.S.

Department of Commerce

U.S. Department of Commerce

2009

Effects of age, sex and reproductive status on persistent organic pollutant concentrations in "Southern Resident" killer whales

Margaret M. Krahn

NOAA Fisheries, peggy.krahn@noaa.gov

M. Bradley Hanson

NOAA Fisheries

Gregory Schorr

Cascadia Research Collective, gschorr@cascadiaresearch.org

Candice K. Emmons

NOAA Fisheries

Douglas G. Burrows

NOAA Fisheries

See next page for additional authors

Follow this and additional works at: https://digitalcommons.unl.edu/usdeptcommercepub

Krahn, Margaret M.; Hanson, M. Bradley; Schorr, Gregory; Emmons, Candice K.; Burrows, Douglas G.; Bolton, Jennie L.; Baird, Robin W.; and Ylitalo, Gina M., "Effects of age, sex and reproductive status on persistent organic pollutant concentrations in "Southern Resident" killer whales" (2009). Publications, Agencies and Staff of the U.S. Department of Commerce. 427.

https://digitalcommons.unl.edu/usdeptcommercepub/427

This Article is brought to you for free and open access by the U.S. Department of Commerce at DigitalCommons@University of Nebraska - Lincoln. It has been accepted for inclusion in Publications, Agencies and Staff of the U.S. Department of Commerce by an authorized administrator of DigitalCommons@University of Nebraska - Lincoln. 


\section{Authors}

Margaret M. Krahn, M. Bradley Hanson, Gregory Schorr, Candice K. Emmons, Douglas G. Burrows, Jennie L. Bolton, Robin W. Baird, and Gina M. Ylitalo 


\title{
Effects of age, sex and reproductive status on persistent organic pollutant concentrations in "Southern Resident" killer whales
}

\author{
Margaret M. Krahn ${ }^{\mathrm{a}, *}$, M. Bradley Hanson ${ }^{\mathrm{a}}$, Gregory S. Schorr ${ }^{\mathrm{b}}$, Candice K. Emmons ${ }^{\mathrm{a}}$, Douglas G. Burrows ${ }^{\mathrm{a}}$, \\ Jennie L. Bolton ${ }^{\mathrm{a}}$, Robin W. Baird ${ }^{\mathrm{b}}$, Gina M. Ylitalo ${ }^{\mathrm{a}}$ \\ ${ }^{a}$ NOAA Fisheries, Northwest Fisheries Science Center, National Marine Fisheries Service, 2725 Montlake Boulevard East, Seattle, WA 98112, USA \\ ${ }^{\mathrm{b}}$ Cascadia Research Collective, 218 1/2 W. 4th Avenue, Olympia, WA 98501, USA
}

\section{A R T I C L E I N F O}

\section{Keywords:}

Biopsy sampling

Persistent organic pollutants

Brominated diphenyl ethers

Endangered species

Stable isotopes

Orcinus orca

\begin{abstract}
A B S T R A C T
"Southern Resident" killer whales (Orcinus orca) that comprise three fish-eating "pods" (J, K and L) were listed as "endangered" in the US and Canada following a 20\% population decline between 1996 and 2001. Blubber biopsy samples from Southern Resident juveniles had statistically higher concentrations of certain persistent organic pollutants than were found for adults. Most Southern Resident killer whales, including the four juveniles, exceeded the health-effects threshold for total PCBs in marine mammal blubber. Maternal transfer of contaminants to the juveniles during rapid development of their biological systems may put these young whales at greater risk than adults for adverse health effects (e.g., immune and endocrine system dysfunction). Pollutant ratios and field observations established that two of the pods (K- and L-pod) travel to California to forage. Nitrogen stable isotope values, supported by field observations, indicated possible changes in the diet of L-pod over the last decade.
\end{abstract}

Published by Elsevier Ltd.

\section{Introduction}

"Resident" killer whales (Orcinus orca) forage, primarily for fish, in coastal areas from California to Alaska in the eastern North Pacific. The "Southern Resident" population includes stable groups of related individuals, termed "pods" (J-, K- and L-pods), that reside in Puget Sound (Washington State), the Strait of Juan de Fuca (between the United States and Canada), and the Strait of Georgia (British Columbia) during the spring, summer, and fall (Balcomb, 1982; Hauser et al., 2007; Osborne, 1986). Photo-identification research begun in 1974 and continued every year since then (Center for Whale Research, 2008) has documented that the Southern Resident population has fluctuated considerably - the first census in 1974 counted 71 whales and the highest count was 97 in 1996. A steep decline of 20\% occurred between 1996 and 2001 (from 97 whales to 78) (Krahn et al., 2004a, 2002). This decline contributed to listing the "Southern Resident" killer whales as "endangered" in Canada in 2001 and the US in 2005. Although the population had rebounded to 91 whales by 2005, the July 2008 count was only 85 individuals (Carretta et al., 2007; Center for Whale Research, 2008). The population decrease in the late 1990s was accompanied by large differences in survival rates among age classes, sexes, and pods, suggesting external causes, such as environmental conditions (e.g., El Niño events) during

\footnotetext{
* Corresponding author. Tel.: +1 206860 3326; fax: +1 2068603335

E-mail address: peggy.krahn@noaa.gov (M.M. Krahn).
}

which prey availability may have changed (Krahn et al., 2002). As an outcome of the endangered species listings in the US and Canada, recovery plans for this population have been prepared that define threats to survival and formulate recovery strategies to mitigate the threats (Fisheries and Oceans Canada, 2008; National Marine Fisheries Service, 2008).

Potential causes cited for the Southern Resident population decline included environmental pollutants, as well as other stressors (e.g., decrease in quantity and quality of prey, increase in marine noise) (Baird, 2001; Krahn et al., 2004a, 2002). Persistent organic pollutants (POPs) comprise both chlorinated [e.g., PCBs, DDTs, chlordanes, hexachlorocyclohexanes $(\mathrm{HCHs})$ and hexachlorobenzene (HCB)] and brominated [e.g., polybrominated diphenyl ethers (PBDEs)] environmental contaminants. A large body of evidence links organochlorine contaminant exposure to a range of deleterious biological effects (e.g., immune, reproductive and endocrine system dysfunction, increased risk of infection) in marine mammals (de Swart et al., 1994; Hall et al., 2006; Jepson et al., 2005; O'Hara and O'Shea, 2001; Ross et al., 1995). Furthermore, immune dysfunction, thyroid disruption and neurotoxicity were observed in laboratory animals exposed to PBDE congeners (de Wit, 2002; Eriksson et al., 2001, 2002). High levels of POPs (e.g., PCBs and DDTs) were found in blubber of eastern North Pacific killer whales in a few early studies (Calambokidis et al., 1984; Hayteas and Duffield, 2000; Jarman et al., 1996; Ross et al., 2000). More recently, Krahn et al. (2007b) reported that Southern Resident killer whale blubber contained $\sum$ PCBs that exceeded thresholds for health ef- 
fects established in captive studies of harbor seal (Ross et al., 1996, 1995).

Chemical "tracers" from prey are incorporated into the tissues of marine predators (e.g., killer whales) and can provide important diet information (Krahn et al., 2007a). For example, stable isotope values of carbon and nitrogen can be measured in the epidermis of whales to assess the geographic area and trophic position at which these animals feed (Kelly, 2000). In addition, patterns and ratios of POPs can provide insight into regional sources of pollutants (e.g., DDTs from local sources in waters off California) transferred from prey to predators (Calambokidis and Barlow, 1991; Krahn et al., 1999, 2007a; Muir et al., 1990). Among the Southern Residents, L-pod whales showed significantly higher ratios of $\sum$ DDTs relative to $\sum$ PCBs than were found for J-pod (Krahn et al., 2007b). Because POPs are acquired over the lifetime of each whale, the differences in this ratio suggested either that these pods were feeding on different prey species or that the areas in which L-pod whales feed have been, at times, spatially distinct from those of J-pod whales. This chemical tracer evidence was supported by field observations, because L-pod has been sighted several times off the coast of California (Black, Unpublished data), whereas J-pod has not been seen in those waters (Osborne, 1999).

This study extends the information reported by Krahn et al. (2007b), by providing a greater sample size from which to draw statistical conclusions. Twelve Southern Resident killer whales (two from J-pod, five from K-pod and five from L-pod) were biopsied in 2007. Each sample was analyzed for POPs, carbon and nitrogen stable isotopes and lipids in order to assess possible changes in the Southern Residents POP levels and diet. Of particular interest was whether the three young whales biopsied for this study had levels of certain POPs as high as those found for the young whale (J39) biopsied in 2006. Furthermore, this study provided the first data on levels of POPs in K-pod whales. In addition, two motheroffspring pairs were biopsied, so relationships between POP levels in these pairs were assessed. Finally, stable isotope values were used to investigate the trophic level at which Southern Residents feed and ratios of particular POPs provided information on regional foraging areas.

\section{Materials and methods}

\subsection{Killer whale photo-identification and sampling}

Since 1974, an annual photographic census has been conducted of all individuals in the Southern Resident population by scientists from the Center for Whale Research (Friday Harbor, WA), so age, sex, and reproductive history have been documented for each whale (Center for Whale Research, 2008). Identities of individual Southern Resident killer whales to be biopsied were determined (and confirmed by photographs) before blubber/epidermis biopsy samples were collected during 2007 from whales in J-pod $(n=2)$, K-pod $(n=5)$ and L-pod $(n=5)$ (Table 1$)$. All samples were obtained using documented sampling techniques (biopsy tips measured $0.6 \times 3.5 \mathrm{~cm}$ ) (Barrett-Lennard, 2000; Hoelzel et al., 1998; Ylitalo et al., 2001). Biopsy samples were stored on ice in the field and then stored at $-80{ }^{\circ} \mathrm{C}$ until analyzed. Each biopsy sample was first split in half lengthwise and then one-half the sample was cut horizontally to a standardized depth of $2 \mathrm{~cm}$ as reported previously (Herman et al., 2005). The remainder (about $3 / 4$ of the sample) was archived at $-80^{\circ} \mathrm{C}$. Because lipid-adjusted POP concentrations are not highly stratified by blubber depth in killer whales (Krahn et al., 2004b), biopsy samples are a good representation of lipid-normalized concentrations in the entire blubber layer.

\subsection{Analyses for persistent organic pollutants and stable isotopes}

Killer whale blubber was analyzed for POP concentrations using the procedure of Sloan et al. (2005). Total lipids were measured by a TLC/FID method (Ylitalo et al., 2005). All POP concentrations in

Table 1

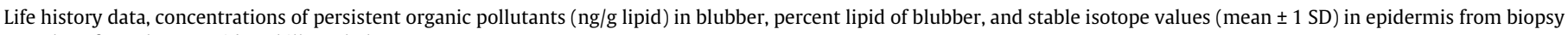
samples of Southern Resident killer whales.

\begin{tabular}{|c|c|c|c|c|c|c|c|c|c|c|c|c|c|c|}
\hline $\begin{array}{l}\text { Whale } \\
\text { ID }^{\mathrm{a}}\end{array}$ & $\begin{array}{l}\text { Sampling } \\
\text { date }\end{array}$ & $\operatorname{Sex}^{a}$ & $\begin{array}{l}\text { Age } \\
\text { (years) }^{\text {a }}\end{array}$ & $\begin{array}{l}\text { Birth } \\
\text { order }^{\text {a }} \text {, }\end{array}$ & $\begin{array}{l}\text { Calves born/ } \\
\text { surviving }{ }^{\mathrm{a}, \mathrm{c}}\end{array}$ & $\begin{array}{l}\text { lipid } \\
(\%)\end{array}$ & $\sum P C B s^{d}$ & $\sum D_{D T s}{ }^{e}$ & $\sum \mathrm{PBDEs}^{\mathrm{f}}$ & $\sum \mathrm{CHLDs}^{\mathrm{g}}$ & $\sum \mathrm{HCHs}^{\mathrm{h}}$ & HCB & $\delta^{13} \mathrm{C}^{\mathrm{i}}$ & $\delta^{15} \mathrm{~N}^{\mathrm{i}}$ \\
\hline \multicolumn{15}{|l|}{$J$-pod } \\
\hline $\mathrm{J} 22$ & $6 / 10 / 07$ & $\mathrm{~F}$ & 22 & 3 & $2 / 2$ & 28.4 & 4600 & 1500 & 880 & 290 & 62 & 76 & $-15.8 \pm 0.07$ & $16.6 \pm 0.08$ \\
\hline $\mathrm{J} 38$ & $6 / 8 / 07$ & M & 4 & 2 & NA & 20.9 & 41,000 & 24,000 & 14,000 & 5100 & 1000 & 1200 & $-15.7 \pm 0.05$ & $16.7 \pm 0.20$ \\
\hline \multicolumn{15}{|l|}{ K-pod } \\
\hline K7 & $12 / 14 / 07$ & $\mathrm{~F}$ & est 97 & $\mathrm{U}$ & $3^{\mathrm{c}} / 1$ & 28.5 & 120,000 & 44,000 & 6700 & 16,000 & 1100 & 650 & $-16.8 \pm 0.04$ & $16.0 \pm 0.18$ \\
\hline K13 & $12 / 14 / 07$ & $\mathrm{~F}$ & 35 & $1^{\mathrm{b}}$ & $4^{c} / 4$ & 22.0 & 8900 & 11,000 & 1200 & 1400 & 300 & 270 & $-16.2 \pm 0.05$ & $15.9 \pm 0.14$ \\
\hline K21 & $12 / 14 / 07$ & $\mathrm{M}$ & 21 & $4^{b}$ & NA & 26.6 & 38,000 & 73,000 & 2900 & 6400 & 410 & 360 & $-16.2 \pm 0.05$ & $16.1 \pm 0.24$ \\
\hline K34 & $12 / 14 / 07$ & $\mathrm{M}$ & 6 & 4 & NA & 22.3 & 39,000 & 61,000 & 10,000 & 7900 & 1200 & 1200 & $-16.5 \pm 0.04$ & $15.7 \pm 0.29$ \\
\hline K36 & $12 / 14 / 07$ & $\mathrm{~F}$ & 4 & $4^{b}$ & NA & 18.3 & 62,000 & 95,000 & 15,000 & 12,000 & 1700 & 2000 & $-16.4 \pm 0.05$ & $16.0 \pm 0.14$ \\
\hline \multicolumn{15}{|l|}{ L-pod } \\
\hline L21 & $6 / 12 / 07$ & $\mathrm{~F}$ & est 57 & $\mathrm{U}$ & $2^{\mathrm{c}} / 1$ & 18.7 & 55,000 & 99,000 & 4200 & 9500 & 750 & 450 & $-16.0 \pm 0.10$ & $16.3 \pm 0.18$ \\
\hline L26 & $9 / 6 / 07$ & $\mathrm{~F}$ & est 51 & $\mathrm{U}$ & $4^{c} / 1$ & 22.1 & 17,000 & 27,000 & 4400 & 3700 & 580 & 500 & $-15.9 \pm 0.08$ & $15.8 \pm 0.21$ \\
\hline L67 & $9 / 11 / 07$ & $\mathrm{~F}$ & 22 & $2^{\mathrm{b}}$ & $2 / 2$ & 29.2 & 5600 & 4300 & 680 & 730 & 150 & 150 & $-15.9 \pm 0.03$ & $15.8 \pm 0.12$ \\
\hline L73 & $9 / 6 / 07$ & $\mathrm{M}$ & 21 & 2 & NA & 23.8 & 32,000 & 55,000 & 3400 & 5500 & 450 & 370 & $-16.3 \pm 0.12$ & $16.1 \pm 0.19$ \\
\hline L87 & $12 / 14 / 07$ & M & 15 & $5^{b}$ & NA & 25.6 & 24,000 & 44,000 & 2600 & 4500 & 410 & 350 & $-16.1 \pm 0.10$ & $16.4 \pm 0.04$ \\
\hline
\end{tabular}

\footnotetext{
a Information from Center for Whale Research (2008). F = female; $M=$ male; $U$ = unknown; est = estimated age; NA = not applicable.

d Sum of all 45 congeners analyzed (Sloan et al., 2005).

e Sum of o, $\mathrm{p}^{\prime}$-DDD, p, $\mathrm{p}^{\prime}$-DDD, p, $\mathrm{p}^{\prime}$-DDE, o, $\mathrm{p}^{\prime}$-DDE, o, $\mathrm{p}^{\prime}$-DDT and p, $\mathrm{p}^{\prime}$-DDT.

f Sum of congeners 28, 47, 49, 66, 85, 99, 100, 153, 154 and 183.

g Sum of oxychlordane, $\gamma$-chlordane, nona-III-chlordane, $\alpha$-chlordane, trans-nonachlor, and cis-nonachlor.

h Sum of $\alpha-, \beta-$, and $\gamma-\mathrm{HCH}$ isomers.

i Mean $( \pm 1 \mathrm{SD})$ of three analyses of each epidermis sample.
}

b The birth order is an estimate; previous siblings may have been born before record keeping began or may have died before being observed.

c The number of calves is an estimated minimum; other calves may have been born before record keeping began. The number of calves "surviving" is from 2008 . 
this paper were calculated using a surrogate (internal) standard (Sloan et al., 2005) and were lipid-normalized. Quality control samples (i.e., method blank, replicate and $S_{R M}{ }^{\circledR} 1945$ ) were analyzed with each set of field samples as described by Sloan et al. (2006). Results obtained were in agreement with certified and reference values published by National Institute of Standards and Technology for $S_{R M}{ }^{\circledR} 1945$. Other quality control samples met established laboratory criteria (Sloan et al., 2006).

Stable isotope analyses were conducted on lipid-extracted epidermis (skin) from killer whale biopsy samples as described previously (Herman et al., 2005). SRM ${ }^{\circledR} 1946$ (National Institute of Standards and Technology) was used as a control material and was analyzed with every 20 analyses to monitor stable isotope analytical accuracy and precision (Sloan et al., 2006). All quality control samples met established laboratory criteria (Sloan et al., 2006).

\subsection{Statistics}

All univariate and multivariate analyses were conducted using JMP Statistical Discovery Software (Mac professional edition, version 5.01). Unless indicated otherwise, all univariate comparisons between two group means were significance tested using a two sample Student's $t$-test assuming unequal variances. Significant differences among multiple groups having equal variances were evaluated using a Tukey HSD test $(\alpha=0.05)$.

Field observers have reported that L87 was associated with Kpod for most of the year prior to biopsy sampling, so its diet may not have been typical of those of other L-pod members (NWFSC, Unpublished data). Therefore, L87 was excluded from the statistical analyses of stable isotope results. However, because contaminants are acquired over a lifetime, L87's year-long association with K-pod would not greatly affect contaminant concentrations, patterns and ratios.

\section{Results and discussion}

\subsection{Concentrations of POPs}

All biopsy samples in this study were analyzed for lipid, POPs and stable isotopes (Table 1). POP concentrations are usually compared among whale groups using adult males, because reproductive female whales transfer a substantial portion of their contaminant burden to their calves (Ross et al., 2000). Concentrations of POPs in females are generally lower than in males and are also partially dependent of the number of times they have given birth (Borga et al., 2004; Ross et al., 2000; Ylitalo et al., 2001). For example, this study showed that three recent mothers (J22; K13; L67) had POP levels lower than those for males of similar ages (Table 1 ). Thus, biases may result when POP data from reproductive female whales are used for comparisons. Levels of POPs in the three male whales from this study (Table 1 and Fig. 1) were in the low to middle portion of the range found for adult males in the earlier study (Krahn et al., 2007b), except that levels of HCHs and HCB were slightly below the ranges observed in that study (Table 1). However, this may be an age-related effect, because the mean age of adult males presented here was 19 years $(n=3$; approximate ages $15,21,21)$ compared to 26 years previously $(n=7 ; 15$, $15,15,18,18,29,55)$ and contaminant concentrations have been reported to increase with age in adult male killer whales (Krahn et al., 2007b; Ross et al., 2000).

In the previous study, J39, a male 3-year-old (at the time of biopsy sampling) was found to have the highest concentrations of $\sum$ PBDEs, $\sum$ HCHs and HCB (Krahn et al., 2007b). Biopsies from three additional juvenile whales (J38, K34, K36) were obtained for this study. POP levels from the new biopsies were compared to those from J39 (Table 1 and Fig. 2). For example, J38 had concentrations (Table 1) comparable to those found for J39 [Fig. 2 and Krahn et al. (2007b)] for all POP groups. Furthermore, the K-pod

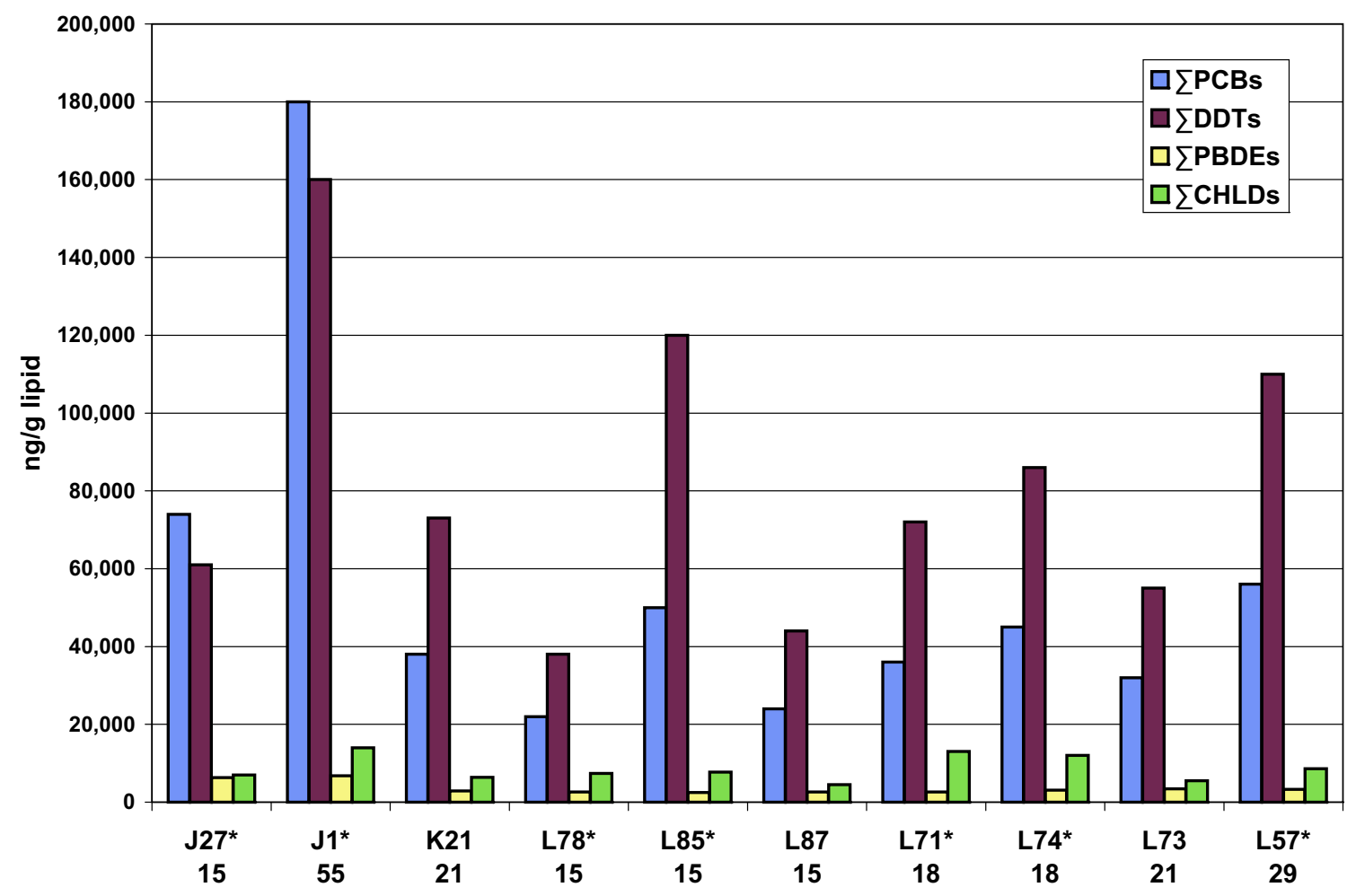

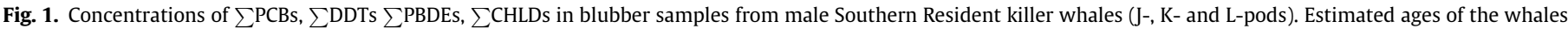
are designated below their ID number. POP concentrations for whales identified with an asterisk (*) were reported in Krahn et al. (2007b). 
juvenile whales (K34 and K36) had blubber concentrations of $\sum$ DDTs and $\sum$ CHLDs that were substantially higher (2-3 times) than those of the J-pod juveniles (Fig. 2). Among the K-pod whales, K36 had the highest levels for all POPs (Table 1 and Fig. 1) compared to the other juvenile (K34) and to all the adult whales, except for the long-lived female (K7, est 97 years). Finally, the young whales (J38, J39, K34 and K36) had statistically higher concentrations of certain contaminants (i.e., $\sum$ PBDEs, $\sum$ HCHs and HCB; $p<0.0001$ ) than were found for adult males from both studies. These new results indicate that the high levels of POPs previously reported for J39 were not anomalous and are found - not only in Jpod juveniles - but also in young whales from K-pod.

\subsection{Transfer of POPs from mother to offspring}

Two mother-offspring pairs of Southern Residents were biopsied in the current study. In the first pair, J38 was the second calf of J22, born 5 years after its first-born sibling (Center for Whale Research, 2008). In the other pair, K34 was the fourth calf of K13, born 7 years after the birth of a previous calf (Center for Whale Research, 2008). Birth order has proven to be a major influence on contaminant levels transferred to killer whale calves from their mothers, with first-borns having the highest levels (Ylitalo et al., 2001). Females can also accumulate POPs between pregnancies (see next paragraph) and then the mother transfers those contaminants to her new calf (Fig. 2). POP concentrations in the juveniles were much higher than in the mothers (Table 1 and Fig. 2). Namely, J38 (4 years) had 8.9-17.6-fold higher concentrations of POPs compared to those measured in its mother J22. Similarly, POP levels in juvenile K34 (6 years) were 4.0-8.3 times higher than those found in its mother K13. A large portion of the mother's POP burden, transferred to the calf during gestation and lactation, is assimilated into its blubber and other tissues. Because the size of the calf is much less than that of the mother, POP concentrations are higher in the calf.

When the transfer of POPs to a calf ceases following lactation, the mother's contaminant levels begin to increase again (Table 2 ). Although senescent females have been reported to show increases in POP levels with increasing age (Ross et al., 2000), no data have been available to determine whether younger females show the same sort of increases in POP concentrations during the nonreproductive years following the birth of a calf. Consequently, simple linear regression analyses were conducted on POP concentrations in female killer whales vs. "years to accumulate POPs" defined as the number of years since a female had her last calf minus 2 years for lactation (Haenel, 1986). Even though only a limited number of animals $(n=6)$ were available for these analyses, statistically significant correlations resulted. For example, the correlations of concentrations for $\sum$ PCBs and $\sum$ CHLDs in reproductive females, as well as those thought to have reached senescence, vs. "years to accumulate" were very strong

Table 2

The number of years Southern Resident killer whale females had to accumulate POPs after weaning their last calf, assuming weaning occurs 2-years post-partum.

\begin{tabular}{lllllll}
\hline Animal ID & J22 & K7 & K13 & L21 & L26 & L67 \\
& F-22y & F-est 97y & F-35y & F-57y & F-51y & F-22y \\
\hline Last calf weaned $^{\mathrm{a}}$ & 2004 & 1956 & 2002 & 1978 & 1994 & 2003 \\
Years to accumulate $^{\mathrm{b}}$ & 2 & 50 & 4 & 28 & 12 & 3 \\
\hline
\end{tabular}

a Arbitrarily, the date the last calf was weaned was chosen to be 2 years after its birth (Haenel, 1986).

b Years between the date the last surviving or observed calf was weaned and the collection of the biopsy sample from the mother.

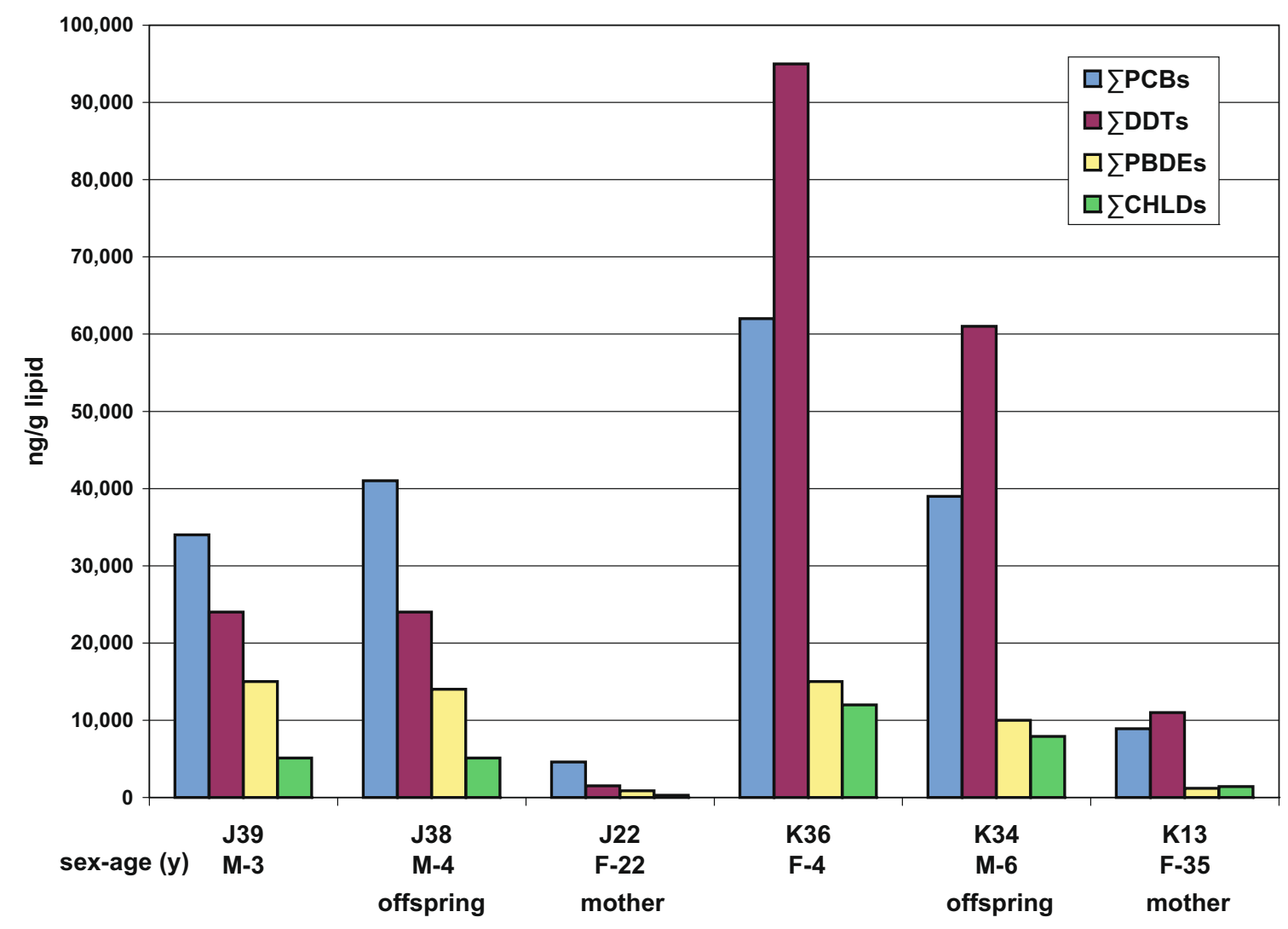

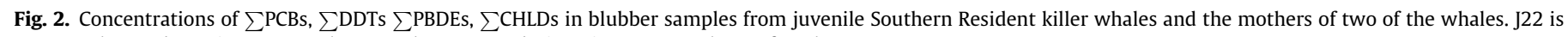
J38's mother and K13 is K34's mother. For the sex-age designations: M = male; F= female. 
( $r^{2}=0.983$ and $0.998, p=0.0001$ and $<0.0001$, respectively). The correlations for $\sum \mathrm{HCH}$ and $\sum$ PDBEs were also strong $\left(r^{2}=0.912\right.$ and $0.847, p=0.003$ and 0.009 , respectively). Although the correlations for HCB and $\sum D D T s$ with "years to accumulate" were not as strong $\left(r^{2}=0.744\right.$ and $0.646, p=0.03$ and 0.166 , respectively), this relationship was significant for HCB. The significant correlations indicated that reproductive females also accumulate certain POPs over the time period between pregnancies at about the same rate as found for senescent females. Because accumulation of $\sum$ DDTs is strongly dependent on the primary foraging sites of the whales' prey (e.g., California Chinook salmon have high $\sum$ DDTs; see Section 3.4), it is not surprising that this contaminant did not correlate with "years to accumulate."

\subsection{Effects of POPs}

Based on captive-feeding studies of harbor seals (Phoca vitulina), Kannan et al. (2000) derived a threshold for PCB-related health effects in marine mammals (17,000 ng/g lipid in blubber) using immune system and endocrine endpoints. All Southern Resident killer whales in this study and the previous one (Krahn et al., 2007b) with the exception of three recent mothers (J22, K13 and L67; see Tables 1 and 2) - had $\sum$ PCBs that exceeded the health-effects threshold reported by Kannan et al. (2000). Most notably, the four juvenile whales exceeded the threshold by factors of 2-3.6 (Table 1 and Fig. 2). Recently, this threshold has been incorporated into risk assessments for cetaceans. For example, Jepson et al. (2005) found that, for harbor porpoises (Phocoena phocoena) having total PCB concentrations in blubber above the marine mammal threshold $(17,000 \mathrm{ng} / \mathrm{g}$ lipid), total PCBs were significantly higher in porpoises that died of infectious disease compared to those that died from acute physical trauma. However, this association was not significant with porpoises having $\mathrm{PCB}$ concentrations below that threshold. In addition, Hickie et al. (2007) have demonstrated the importance of age and sex in determining health risks from PCBs and found the killer whale population segments most at risk were adult males and young juveniles and least at risk were neonates and reproductive females. Their results showed that nursing killer whales can go from being the least to the most contaminated members of the population in about 1 year because of the rapid transfer of POPs from the mother during lactation (Cockcroft et al., 1989) before a significant amount of growth dilution occurs (Hickie et al., 1999, 2007). Thus, maternal transfer of POPs to juvenile Southern Residents has resulted in high levels during a period when their biological systems are undergoing rapid development (Eriksson et al., 2006, 2002; Viberg et al., 2003), so these juveniles may be at greater risk than adults for POP-related health effects. Furthermore, a contaminant risk model developed by Schwacke et al. (2002) is consistent with low survivorship in calves exposed to high POPs levels from maternal transfer. Consequently, it is apparent that a large proportion of the Southern Resident killer whale population, and particularly the young whales, is at risk for serious health effects.

During the approximately $20 \%$ decline of the Southern Resident killer whale population experienced in the mid-1990s, survivorship was lowest for calves, adult males and post-reproductive females (Krahn et al., 2004a, 2002). Furthermore, it has been demonstrated in the current and other recent studies of Southern Residents (Krahn et al., 2007b; Ross et al., 2000) that the highest levels of POPs occurred in juveniles, adult males and post-reproductive females. Although direct evidence for effects of POPs on survival of this population is lacking, certain lines of evidence support the role of contaminants in the 1990s population decline. For example, a strong correlation was reported by Ford et al. (2005) between the increased mortality of Southern Residents in the mid1990s and decreased abundance of Chinook salmon, a preferred prey item (Ford and Ellis, 2006). Because the Southern Residents likely experienced poorer nutrition due to decreased availability of prey, lipid stores would have been metabolized to meet energetic needs and the associated lipophilic POPs would have been released from blubber to circulate in blood. In male bottlenose dolphins, a decline in immune function occurred as contaminant concentrations increased in the blood (Lahvis et al., 1995). Thus, during the 1990s when Southern Resident prey was limited and lipid stores were likely needed to provide energy, these killer whales may have experienced immune suppression as a result of high levels of circulating POPs, thus increasing their risk of disease (Hall et al., 2006; Jepson et al., 2005) or other pollutant-related health effects.

\subsection{POP ratios}

The ratios of certain POPs in marine mammals can provide insight into whales' forging locations (Calambokidis and Barlow, 1991; Krahn et al., 2007a; Muir et al., 1990). For example, mean $\sum$ DDTs/ $\sum$ PCBs ratios of whales from K-pod and L-pod were not significantly different from each other $(1.68 \pm 0.19$ and $1.93 \pm 0.08$, respectively), but were significantly higher than the ratio of J-pod $(0.72 \pm 0.24)$. The similarity of K- and L-pod ratios suggests that K-pod, in addition to L-pod (Krahn et al., 2007b), travels to forage on prey that reside in California, where high levels of DDTs are found in the marine environment (the "California signature"). These results have been substantiated by multiple sightings of both K- and L-pods in waters off the coast of California (Krahn et al., 2007b; NWFSC, Unpublished data). Furthermore, both pods have been observed feeding on salmon in Monterey Bay (Black et al., 2001). As reported previously, support for the "California signature" in K- and L-pods can be found by examining $\sum$ DDTs/ $\sum$ PCBs ratios in prey (Krahn et al., 2007b). For example, the $\sum$ DDTs/ $\sum$ PCBs ratios in Chinook salmon from California $(n=10$; $2.60 \pm 0.50)$ and the Columbia River $(n=10 ; 1.17 \pm 0.23)$ indicated higher $\sum$ DDT compared to $\sum$ PCBs, whereas those of Chinook from the Fraser River $(n=13 ; 0.73 \pm 0.21)$ or Puget Sound (resident "blackmouth;" $n=26 ; 0.24 \pm 0.29$ ) reflected a lower ratio (O'Neill et al., 2006). Given the whales' preference for Chinook salmon (Ford and Ellis, 2006) and because Chinook from the Central Valley of California are thought to remain in California waters (Myers et al., 1998), these salmon likely contributed to the relatively high DDT levels observed in K- and L-pods. In contrast, J-pod has not been observed in California waters and is more frequently observed than the other pods (Hauser et al., 2007) in Puget Sound/ Georgia Basin waters where prey that have low $\sum$ DDTs relative to $\sum$ PCBs (O'Neill et al., 2006).

\subsection{Stable isotopes}

Decreased quantity and quality of prey are likely risk factors in the population decline of Southern Resident killer whales (Baird, 2001; Ford and Ellis, 2005; Krahn et al., 2004a, 2002). Southern Residents are reported to prefer Chinook salmon (Oncorhynchus tshawytscha) (Ford and Ellis, 2006) over other potential prey species (e.g., groundfish, herring and other salmon species) that are generally of lower trophic levels (O'Neill et al., 2006). Nitrogen stable isotope values are often used to assess the trophic level at which marine mammals feed $\left(\delta^{15} \mathrm{~N}\right.$ values increase as trophic level increases) and carbon values are indicative of offshore vs. nearshore feeding $\left(\delta^{13} \mathrm{C}\right.$ values decrease as distance from shore increases) (Kelly, 2000). Thus, $\delta^{15} \mathrm{~N}$ and $\delta^{13} \mathrm{C}$ values were determined in the epidermis of Southern Resident killer whales to gain information about their diet (Table 1). Hicks et al. (1985) reported that a complete isotope turnover of skin cells in bottlenose dolphins was estimated to take 73 days, but changes in stable 
isotope values were apparent within a month of the diet change. Therefore, stable isotope values in Southern Residents - assuming epidermis turnover is similar to that of bottlenose dolphins - reflect their diet in the previous month or two.

Stable isotope values of nitrogen and carbon measured in the whales did not differ significantly between J-pod $(n=6)$ and Lpod $(n=6)$ (Table 3 ). In contrast, K-pod had significantly lower $\delta^{13} \mathrm{C}$ values compared to the other two pods and had significantly lower $\delta^{15} \mathrm{~N}$ values than those of J-pod, but not L-pod (Table 3 ). However, all K-pod samples were collected in December 2007 $(n=5)$ and J-pod samples were collected in May and June, 2006/ $2007(n=6)$. L-pod had the widest range of sampling dates (L87 was excluded; see Methods) - May/June $2006(n=2)$, June 2007 $(n=1)$ and September $2007(n=3)$.

The carbon and nitrogen stable isotope results for J- and L-pods were comparable to previous results reported for these pods by Krahn et al. (2007b), so the pods appear to be consuming prey from the same trophic level and region. However, only K-pod samples were collected in December, so the differences in K-pod carbon and nitrogen stable isotope values compared to the other pods might reflect seasonal variations, as well as differences in trophic levels and foraging regions. For example, the $\delta^{13} \mathrm{C}$ differences between K-pod and the other pods could result from seasonal changes in stable isotope ratios at the base of the food chain. Alternatively, K-pod's lower $\delta^{13} \mathrm{C}$ values might result from these whales consuming a larger proportion of prey that feed in "offshore" areas compared to the other whales. Furthermore, K-pod's $\delta^{15} \mathrm{~N}$ value was significantly lower than that of J-pod, so these results could point to seasonal changes in diet. Field data support stable isotope results showing diet differences among the killer whale pods. Salmon species available in Puget Sound vary on a seasonal basis (Washington Department of Fish and Wildlife, 1993), the whales have been observed to consume salmon from different species and populations during different seasons (NWFSC, Unpublished data) and field observations indicate that $\mathrm{K}$ - and L-pods spend more time outside of Puget Sound/Georgia Basin waters than Jpod does (Osborne, 1999).

Previously, it was demonstrated that stable isotope values of carbon and nitrogen measured in epidermis samples from three L-pod whales sampled in 1996 did not differ greatly from those of L-pod whales sampled in 2006, but the sample size was small ( $n=3$ in 1996 and $n=2$ in 2006) (Krahn et al., 2007b). In 2007, additional biopsies were acquired from L-pod whales and the combined results from 2006/2007 ( $n=6$ excluding L87; Table 2) showed that the nitrogen $(p=0.05)$, but not the carbon, stable isotope values were significantly different (lower) than those of L-pod sampled in 1996. However, three of six biopsies from 2006/2007 were taken in early September, whereas the other three were collected in May and June. Therefore, to minimize seasonal variation, the 1996 samples collected in late September and early October $(17.0 \pm 0.4$, ) were compared to the September 2007 biopsies

Table 3

Stable isotope values (mean \pm 1 SD) in 2006/2007 epidermis samples from Southern Resident killer whales compared to those from 1996.

\begin{tabular}{lll}
\hline Mean \pm SD & $\delta^{13} \mathrm{C}$ & $\delta^{15} \mathrm{~N}$ \\
\hline J-pod $(2006 / 2007 ; n=6)^{\mathrm{a}}$ & $-15.7 \pm 0.27$ & $16.4 \pm 0.23$ \\
K-pod $(2007 ; n=5)$ & $-16.4 \pm 0.25$ & $15.9 \pm 0.15$ \\
L-pod $(2006 / 2007 ; n=6)^{\mathrm{b}}$ & $-16.0 \pm 0.20$ & $16.2 \pm 0.46$ \\
L-pod $(1996 ; n=3)^{\mathrm{c}}$ & $-15.9 \pm 0.20$ & $17.0 \pm 0.37$ \\
\hline
\end{tabular}

a Mean ( \pm 1 SD) for biopsy samples from this study and from Krahn et al. (2007b).

b Mean ( $\pm 1 \mathrm{SD})$; 287 has been omitted from the mean because this whale had been foraging with the K-pod for approximately 1 year.

${ }^{c}$ Mean $( \pm 1$ SD) from biopsy samples collected in 1996 and reported by Krahn et al. (2007b).
$(15.9 \pm 0.2)$ and a larger significant decrease in $\delta^{15} \mathrm{~N}$ values was observed $(p=0.009)$. Field data (Baird et al., 2005) have suggested there may have been a shift in diet from 1993 through 2002 based on differences in dive depths of Southern Resident killer whales instrumented with time-depth recorders. Thus, these results indicate a possible change in the diet of L-pod Southern Residents over the last decade, suggesting that Southern Residents consume fish species other than Chinook salmon, particularly in the fall months.

\section{Conclusions}

In conclusion, juvenile Southern Resident killer whales had statistically higher concentrations of certain contaminants (i.e., $\sum$ PBDEs, $\sum$ HCHs and HCB) than were found for adult males and these results confirmed the high levels of POPs previously reported for a single juvenile whale. Furthermore, all Southern Resident killer whales - with the exception of three recent mothers - exceeded the health-effects threshold for total PCBs in blubber and, most notably, the four juvenile whales exceeded the threshold by factors of 2-3.6. Thus, maternal transfer of POPs to the juvenile Southern Residents has resulted in high POP levels during a period when their biological systems are undergoing rapid development, so these juveniles may be at greater risk than adults for POP-related health effects (e.g., immune and endocrine system dysfunction).

The similarity of the $\sum$ DDTs/ $\sum$ PCBs ratios for K- and L-pods, in contrast to the lower ratio for J-pod, suggests that both K-pod and L-pod travel to California to forage, where high levels of DDTs are found in prey. In contrast, J-pod generally remains near Puget Sound/Georgia Basin waters where prey has lower $\sum D D T s / \sum$ PCBs ratios. These results have been substantiated by multiple sightings of both K- and L-pods, but not J-pod, in waters off the coast of central California. Nitrogen stable isotope values, as well as field observations, indicated a possible change in the diet of L-pod Southern Residents over the last decade, suggesting that Southern Residents consume fish species other than the preferred Chinook salmon, particularly in the fall months.

\section{Acknowledgments}

We greatly appreciate the technical assistance of D.W. Brown, C.A. Sloan, R.H. Boyer, D. Boyd, K. Tilbury and G. Yanagida in sample and data analyses. We value Ken Balcomb's assistance in obtaining killer whale sex and age data, the operators in the whale watching fleet who provided whale sightings and also gave scientists space to work and the numerous volunteers who assisted in the field. Logistical support was provided by the University of Washington Friday Harbor Laboratories. Research was undertaken in US waters under National Marine Fisheries Service Scientific Research Permit No. 781-1824-01.

\section{References}

Baird, R.W., 2001. Status of killer whales, Orcinus orca, in Canada. Canadian FieldNaturalist 115, 676-701.

Baird, R.W., Hanson, M.B., Dill, L.M., 2005. Factors influencing the diving behaviour of fish-eating killer whales: sex differences and diel and interannual variation in diving rates. Canadian Journal of Zoology-Revue Canadienne De Zoologie 83, 257-267.

Balcomb III, K.C., 1982. The Occurrence and Status of Three Resident Pods of Killer Whales in Greater Puget Sound, State of Washington. Ocean Research and Education Society, Gloucester, Massachusetts.

Barrett-Lennard, L.G., 2000. Population Structure and Mating Patterns of Killer Whales as Revealed by DNA Analysis. Ph.D. Thesis, University of British Columbia, Vancouver, BC.

Black, N., Ternullo, R., Schulman-Janiger, A., Hammers, A.M., Stap, P., 2001. Occurrence, behavior, and photo-identification of killer whales in Monterey Bay, California. In: 14th Biennial Conference on the Biology of Marine Mammals. Society for Marine Mammalogy, San Francisco, California, Vancouver, British Columbia, Canada.

Black, N., Unpublished data. Monterey Bay Cetacean Project. 
Borga, K., Fisk, A.T., Hoekstra, P.F., Muir, D.C.G., 2004. Biological and chemical factors of importance in the bioaccumulation and trophic transfer of persistent organochlorine contaminants in arctic marine food webs. Environmental Toxicology and Chemistry 23, 2367-2385.

Calambokidis, J., Barlow, J., 1991. Chlorinated hydrocarbon concentrations and their use for describing population discreteness in harbor porpoises from Washington, Oregon and California. In: Reynolds, J.E., Odell, D.K. (Eds.), Marine Mammal Strandings in the United States: Proceedings of the Second Marine Mammal Stranding Workshop; 3-5 December 1987, Miami, FL. NOAA Technical Report NMFS 98.

Calambokidis, J., Peard, J., Steiger, G., Cubbage, J., DeLong, R.L., 1984. Chemical Contaminants in Marine Mammals from Washington State. Tech. Memo. F/ NWC-6. US Department of Commerce, 167pp.

Carretta, J.V., Forney, K.A., Muto, M.M., Barlow, J., Baker, J., Hanson, M.B., Lowry, M.S., 2007. US Pacific Marine Mammal Stock Assessments: 2006 NOAA-TMNMFS-SWFSC-398. US Department of Commerce, La Jolla, CA, USA, 312pp.

Center for Whale Research, 2008. <http://www.whaleresearch.com/thecenter/ research.html>.

Cockcroft, V.G., Dekock, A.C., Lord, D.A., Ross, G.J.B., 1989. Organochlorines in BottleNosed Dolphins Tursiops-Truncatus from the East Coast of South-Africa. South African Journal of Marine Science-Suid-Afrikaanse Tydskrif Vir Seewetenskap 8, 207-217.

de Swart, R.L., Ross, P.S., Vedder, L.J., Timmerman, H.H., Heisterkamp, S., Loveren H.V., Vos, J.G., Reijnders, P.J.H., Osterhaus, A.D.M.E., 1994. Impairment of immune function in harbour seals (Phoca vitulina) feeding on fish from polluted waters. Ambio 23, 155-159.

de Wit, C.A., 2002. An overview of brominated flame retardants in the environment. Chemosphere 46, 583-624.

Eriksson, P., Fischer, C., Fredriksson, A., 2006. Polybrominated diphenyl ethers, a group of brominated flame retardants, can interact with polychlorinated biphenyls in enhancing developmental neurobehavioral defects. Toxicological Sciences 94, 302-309.

Eriksson, P., Jakobsson, E., Fredriksson, A., 2001. Brominated flame retardants: a novel class of developmental neurotoxicants in our environment? Environmental Health Perspectives 109, 903-908.

Eriksson, P., Viberg, H., Jakobsson, E., Orn, U., Fredriksson, A., 2002. A brominated flame retardant, 2,2',4,4',5-pentabromodiphenyl ether: uptake, retention, and induction of neurobehavioral alterations in mice during a critical phase of neonatal brain development. Toxicological Sciences 67, 98-103.

Fisheries and Oceans Canada, 2008. Recovery strategy for the northern and southern resident killer whales (Orcinus orca) in Canada. Species at Risk Act Recovery Strategy Series, Fisheries and Oceans Canada, Ottawa, ix+81pp.

Ford, J.K.B., Ellis, G.M., 2005. Prey Selection and Food Sharing by Fish-eating 'Resident' Killer Whales (Orcinus orca) in British Columbia. <http://www.dfompo.gc.ca/csas/Csas/Publications/ResDocs-DocRech/2005/2005_041_e.htm>

Ford, J.K.B., Ellis, G.M., Olesiuk, P.F., 2005. Linking Prey and Population Dynamics: did Food Limitation cause Recent Declines of 'Resident' Killer Whales (Orcinus orca) in British Columbia. Research Document 2005/042. <http://www.dfo-mpo.gc.ca/ csas/>, Canadian Science Advisory Secretariat.

Ford, J.K.B., Ellis, G.M., 2006. Selective foraging by fish-eating killer whales Orcinus orca in British Columbia. Marine Ecology Progress Series 316, 185-199.

Haenel, N.J., 1986. General notes on the behavioral ontogeny of Puget Sound killer whales and the occurrence of allomaternal behavior. In: Kirkevold, B.C., Lockard, J.S. (Eds.), Behavioral Biology of Killer Whales. Alan R. Liss Inc., New York, NY, USA, pp. 285-300.

Hall, A.J., Hugunin, K., Deaville, R., Law, R.J., Allchin, C.R., Jepson, P.D., 2006. The risk of infection from polychlorinated biphenyl exposure in the harbor porpoise (Phocoena phocoena): a case-control approach. Environmental Health Perspectives 114, 704-711.

Hauser, D.D.W., Logsdon, M.G., Holmes, E.E., VanBlaricom, G.R., Osborne, R.W., 2007. Summer distribution patterns of southern resident killer whales Orcinus orca: core areas and spatial segregation of social groups. Marine Ecology Progress Series 351, 301-310.

Hayteas, D.L., Duffield, D.A., 2000. High levels of PCB and p,p'-DDE found in the blubber of killer whales (Orcinus orca). Marine Pollution Bulletin 40, 558561.

Herman, D.P., Burrows, D.G., Wade, P.R., Durban, J.W., LeDuc, R.G., Matkin, C.O., Krahn, M.M., 2005. Feeding ecology of eastern North Pacific killer whales from fatty acid, stable isotope, and organochlorine analyses of blubber biopsies. Marine Ecology Progress Series 302, 275-291.

Hickie, B.E., Mackay, D., de Koning, J., 1999. Lifetime pharmacokinetic model for hydrophobic contaminants in marine mammals. Environmental Toxicology and Chemistry 18, 2622-2633.

Hickie, B.E., Ross, P.S., Macdonald, R.W., Ford, J.K.B., 2007. Killer whales (Orcinus orca) face protracted health risks associated with lifetime exposure to PCBs. Environmental Science and Technology 41, 6613-6619.

Hicks, B.D., St. Aubin, D.J., Geraci, J.R., Brown, W.R., 1985. Epidermal growth in the bottlenose dolphin, Tursiops truncatus. Journal of Investigative Dermatology 85, 60-63.

Hoelzel, A.R., Dahlheim, M., Stern, S.J., 1998. Low genetic variation among killer whales (Orcinus orca) in the eastern north Pacific and genetic differentiation between foraging specialists. Journal of Heredity 89, 121-128.

Jarman, W.M., Norstrom, R.J., Muir, D.C.G., Rosenberg, B., Simon, M., Baird, R.W., 1996. Levels of organochlorine compounds, including PCDDS and PCDFS, in the blubber of cetaceans from the west coast of North America. Marine Pollution Bulletin 32, 426-436.
Jepson, P.D., Bennett, P.M., Deaville, R., Allchin, C.R., Baker, J.R., Law, R.J., 2005 Relationships between polychlorinated biphenyls and health status in harbor porpoises (Phocoena phocoena) stranded in the United Kingdom. Environmental Toxicology and Chemistry 24, 238-248.

Kannan, K., Blankenship, A.L., Jones, P.D., Giesy, J.P., 2000. Toxicity reference values for the toxic effects of polychlorinated biphenyls to aquatic mammals. Human and Ecological Risk Assessment 6, 181-201.

Kelly, J.F., 2000. Stable isotopes of carbon and nitrogen in the study of avian and mammalian trophic ecology. Canadian Journal of Zoology 78, 1-27.

Krahn, M.M., Burrows, D.G., Stein, J.E., Becker, P.R., Schantz, M.M., Muir, D.C., O’Hara T.M., 1999. White whales (Delphinapterus leucas) from three Alaskan stocks: concentrations and patterns of persistent organochlorine contaminants in blubber. Journal of Cetacean Research and Management 1, 239-249.

Krahn, M.M., Ford, M.J., Perrin, W.F., Wade, P.R., Angliss, R.P., Hanson, M.B., Taylor B.L., Ylitalo, G.M., Dahlheim, M.E., Stein, J.E., Waples, R.S., 2004a. 2004 Status Review of Southern Resident Killer Whales (Orcinus orca) under the Endangered Species Act. US Department of Commerce, NOAA Tech. Memo. NMFS-NWFSC62, Seattle, WA, xvii+73pp.

Krahn, M.M., Hanson, M.B., Baird, R.W., Boyer, R.H., Burrows, D.G., Emmons, C.K. Ford, J.K.B., Jones, L.L., Noren, D.P., Ross, P.S., Schorr, G.S., Collier, T.K., 2007a. Persistent organic pollutants and stable isotopes in biopsy samples $(2004 / 2006)$ from Southern Resident killer whales. Marine Pollution Bulletin 54, 1903-1911.

Krahn, M.M., Herman, D.P., Matkin, C.O., Durban, J.W., Barrett-Lennard, L., Burrows, D.G., Dahlheim, M.E., Black, N., LeDuc, R.G., Wade, P.R., 2007b. Use of chemical tracers in assessing the diet and foraging regions of eastern North Pacific killer whales. Marine Environmental Research 63, 91-114.

Krahn, M.M., Herman, D.P., Ylitalo, G.M., Sloan, C.A., Burrows, D.G., Hobbs, R.C. Mahoney, B.A., Yanagida, G.K., Calambokidis, J., Moore, S.E., 2004b. Stratification of lipids, fatty acids and organochlorine contaminants in blubber of white whales and killer whales. Journal of Cetacean Research and Management 6, $175-189$.

Krahn, M.M., Wade, P.R., Kalinowski, S.T., Dahlheim, M.E., Taylor, B.L., Hanson, M.B., Ylitalo, G.M., Angliss, R.P., Stein, J.E., Waples, R.S., 2002. Status Review of Southern Resident Killer Whales (Orcinus orca) under the Endangered Species Act. US Department of Commerce, NOAA Tech. Memo. NMFS-NWFSC-54 Seattle, WA, xxii+133pp.

Lahvis, G.P., Wells, R.S., Kuehl, D.W., Stewart, J.L., Rhinehart, H.L., Via, C.S., 1995 Decreased lymphocyte-responses in free-ranging bottlenose dolphins (Tursiops truncatus) are associated with increased concentrations of PCBs and DDTs in peripheral-blood. Environmental Health Perspectives 103, 67-72.

Muir, D., Ford, C., Stewart, R., Smith, T., Addison, R., Zinck, M., Beland, P., 1990 Organochlorine contaminants in belugas, Delphinapterus leucas, from Canadian waters. Canadian Bulletin of Fisheries and Aquatic Sciences 224, 165-190.

Myers, J.M., Kope, R., Bryant, G., Teel, D., Lierheimer, L., Wainwright, T., Grant, W.S. Waknitz, F.W., Neely, K., Lindley, S., Waples, R., 1998. Status Review of Chinook Salmon from Washington, Idaho, Oregon, and California. NOAA Tech. Memo NMFS-NWFSC-35, NMFS, US Department of Commerce, Seattle, WA, 443pp.

National Marine Fisheries Service, 2008. Recovery Plan for Southern Resident Killer Whales (Orcinus orca). National Marine Fisheries Service, Northwest Region, Seattle, Washington.

NWFSC, Unpublished data.

O'Hara, T.M., O'Shea, T.J., 2001. Toxicology. In: Dierauf, L.A., Gulland, F.M.D. (Eds.), CRC Handbook of Marine Mammal Medicine, second ed. CRC Press, Boca Raton, FL, pp. 471-520.

O’Neill, S.M., Ylitalo, G.M., West, J.E., Bolton, J., Sloan, C.A., Krahn, M.M., 2006 Regional patterns of persistent organic pollutants in five Pacific salmon species (Oncorhynchus spp) and their contributions to contaminant levels in northern and southern resident killer whales (Orcinus orca). In: 2006 Southern Resident Killer Whale Symposium, NOAA-Fisheries, Northwest Fisheries Science Center, Seattle, WA.

Osborne, R., 1999. A Historical Ecology of Salish Sea. A Resident Killer Whales (Orcinus orca): With Implications for Management. Ph.D. Dissertation, University of Victoria, Victoria, BC, Canada.

Osborne, R.W., 1986. A behavioral budget of Puget Sound killer whales. In: Kirkevold, B., Lockard, J.S. (Eds.), Behavioral Biology of Killer Whales. Alan R. Liss Inc., New York, NY, pp. 211-249.

Ross, P.S., DeSwart, R., Addison, R., VanLoveren, H., Vos, J., Osterhaus, A., 1996 Contaminant-induced immunotoxicity in harbour seals: wildlife at risk? Toxicology 112, 157-169.

Ross, P.S., DeSwart, R.L., Reijnders, P.J.H., van Loveren, H., Vos, J.G., Osterhaus A.D.M.E., 1995. Contaminant-related suppression of delayed-type hypersensitivity and antibody responses in harbor seals fed herring from the Baltic Sea. Environmental Health Perspectives 103, 162-167.

Ross, P.S., Ellis, G.M., Ikonomou, M.G., Barrett-Lennard, L.G., Addison, R.F., 2000 High PCB concentrations in free-ranging Pacific killer whales, Orcinus orca: effects of age, sex and dietary preference. Marine Pollution Bulletin 40, 504515.

Schwacke, L.H., Voit, E.O., Hansen, L.J., Wells, R.S., Mitchum, G.B., Hohn, A.A., Fair, P.A., 2002. Probabilistic risk assessment of reproductive effects of polychlorinated biphenyls on bottlenose dolphins (Tursiops truncatus) from the southeast United States coast. Environmental Toxicology and Chemistry 21 $2752-2764$.

Sloan, C.A., Brown, D.W., Pearce, R.W., Boyer, R.H., Bolton, J.L., Burrows, D.G., Herman, D.P., Krahn, M.M., 2005. Determining aromatic hydrocarbons and chlorinated hydrocarbons in sediments and tissues using accelerated solvent extraction and gas chromatography/mass spectrometry. In: Ostrander, G.K. 
(Ed.), Techniques in Aquatic Toxicology, vol. 2. CRC Press, Boca Raton, FL, pp. 631-651.

Sloan, C.A., Brown, D.W., Ylitalo, G.M., Buzitis, J., Herman, D.P., Burrows, D.G. Yanagida, G.K., Krahn, M.M., 2006. Quality Assurance Plan for Analyses of Environmental Samples for Polycyclic Aromatic Compounds, Persistent Organic Pollutants, Fatty Acids, Stable Isotope Ratios, Lipid Classes, and Metabolites of Polycyclic Aromatic Compounds. NOAA Tech. Memo NMFS-NWFSC-77, NMFS US Department of Commerce, Seattle, WA, USA

Viberg, H., Fredriksson, A., Jakobsson, E., Orn, U., Eriksson, P., 2003. Neurobehavioral derangements in adult mice receiving decabrominated diphenyl ether (PBDE 209) during a defined period of neonatal brain development. Toxicological Sciences 76, 112-120.

Washington Department of Fish and Wildlife, 1993. 1992 Washington State Salmon and Steelhead Stock Inventory (SASSI), March 1993. Washington Department of
Fisheries (WDF), Washington Department of Wildlife, and Western Washington Treaty Indian Tribes, Olympia, WA (Available Environmental and Technical Services Division, Natl. Mar. Fish. Serv., 525 N.E. Oregon Street, Portland, OR 97232.), 212pp.

Ylitalo, G.M., Matkin, C.O., Buzitis, J., Krahn, M.M., Jones, L.L, Rowles, T, Stein, J.E. 2001. Influence of life-history parameters on organochlorine concentrations in free-ranging killer whales (Orcinus orca) from Prince William Sound, AK. Science of the Total Environment 281, 183-203.

Ylitalo, G.M., Yanagida, G.K., Hufnagle Jr., L., Krahn, M.M., 2005. Determination of lipid classes and lipid content in tissues of aquatic organisms using a thin layer chromatography/flame ionization detection (TLC/FID) microlipid method. In: Ostrander, G.K. (Ed.), Techniques in Aquatic Toxicology, vol. 2. CRC Press, Boca Raton, FL, USA, pp. 449-464 